Susan E. Myers

\title{
Spirit Epicleses in the Acts of Thomas
}

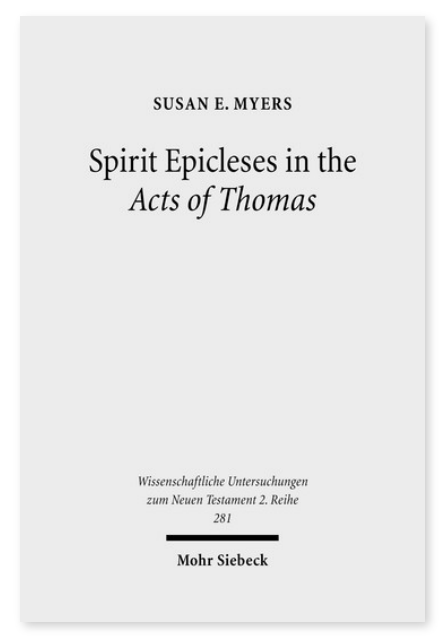

2010. XVI, 268 Seiten. WUNT II 281

ISBN 978-3-16-151624-5

DOI 10.1628/978-3-16-151624-5

eBook PDF 74,00€

ISBN 978-3-16-149472-7

fadengeheftete Broschur $74,00 €$
[Geistliche Epiklese in den Thomasakten.]

Veröffentlicht auf Englisch.

Susan E. Myers untersucht zwei Gebete, die sich in Stil und Inhalt sehr ähneln und aus den Thomasakten aus dem 3. Jahrhundert stammen. Jedes Gebet steht im Zusammenhang eines christlichen Initiationsritus und ist an eine weibliche Gottheit gerichtet, die aufgefordert wird, bei diesem Ritual anwesend zu sein. Die Gebete wenden sich an ein weibliches Wesen, das unter anderem 'Mutter', 'Begleitung des Mannes' oder 'Taube' genannt wird. Die Autorin untersucht diese Gebete in ihren historischen, literarischen und liturgischen Zusammenhängen. Damit stellt sie einige der bisher vorherrschenden Annahmen über die syrischsprechende Christenheit im allgemeinen und die Thomasakten im besonderen in Frage.

Susan E. Myers Born 1958; PhD from University of Notre Dame in Christianity and Judaism in Antiquity; currently Associate Professor in the Theology Department at the University of St. Thomas, St. Paul, MN, USA.

Jetzt bestellen:

https://mohrsiebeck.com/buch/spirit-epicleses-in-the-acts-of-thomas-9783161516245?no cache=1

order@mohrsiebeck.com

Telefon: +49 (0)7071-923-17

Telefax: +49 (0)7071-51104 